\title{
Engineered DNA Polymerases in Biotechnology
}

\author{
Ramon Kranaster ${ }^{[a, b]}$ and Andreas Marx ${ }^{*[a]}$ \\ Dedicated to Professor Bernd Giese on the occasion of his 70th birthday.
}

\section{Introduction}

DNA polymerases are the enzymes that catalyse all DNA synthesis in Nature often with astounding speed and accuracy. Consequently, their features as molecular machines are exploited in a wide range of biotechnological applications. Some features are highlighted in the following.

For example, DNA polymerases are useful enzymes to detect genomic alterations that can lead to the development of certain diseases such as cancer or to promote toxic side effects of drugs. Methods for the detection of single-nucleotide polymorphisms, copy-number variations and somatic copy-number alterations are important for the realisation of personalised medicine. ${ }^{[1-3]}$ Additionally, new DNA sequencing technologies aim to achieve the "\$ 1000 genome" that might further drive a new era of specific pharmaceutical treatments and diseaseprevention strategies based on an individual's genome. ${ }^{[4-7]}$ In many DNA diagnostic and sequencing methods, the accurate action of a DNA polymerase to incorporate the right nucleotide with high selectivity, according to the Watson-Crick rule, is crucial.

Since the polymerase chain reaction $(\mathrm{PCR})^{[8]}$ was developed, the biotechnology field has been revolutionised. Thermostable DNA polymerases such as Thermus aquaticus (Taq) DNA polymerase opened the field to nowadays standard procedures such as (multiplex) PCR for the amplification of (different) DNA fragments in one reaction vessel, ${ }^{[9]}$ nested $P C R$, which increases the specificity of the DNA amplification reaction, ${ }^{[10]}$ quantitative PCR to quantify and compare certain DNA strands, ${ }^{[11]}$ reverse transcription PCR for the detection of RNA targets, ${ }^{[12,13]}$ allelespecific PCR for the detection of single nucleotide variations ${ }^{[14,15]}$ and many more. In the age in which new viruses like the influenza A virus subtype H1N1 (swine flu) ${ }^{[16]}$ threaten the human population, reliable and fast pathogen-detection systems are needed to monitor break-outs and spread. ${ }^{[17]}$ Besides several antibody-based assays like the hemagglutination inhibition test, enzyme immunoassays, and virus-neutralization tests, ${ }^{[13]}$ one of the most reliable and commonly used techniques for pathogen detection is $\mathrm{PCR}{ }^{[8]}$ It is clear that those different PCR methods set their own specific requirements for a DNA polymerase, for example, good single-nucleotide discrimination properties in the case of allele-specific PCR or high accuracy in the case of cloning procedures. Recently developed DNA polymerase variants, for example with an increased resistance against common inhibitors from blood and soil, will render these methods faster, more robust and reliable. ${ }^{[18]}$
Besides the genetic DNA sequence, it is known that modifications of deoxycytidines $(\mathrm{dC})$ such as methylation at the 5-position play an important role in the regulation of chromatin structure and influencing gene expression. ${ }^{[19]}$ Detection of those methylation states can be achieved by sequencing or methylation-specific PCR. Initially, unmethylated dCs are transformed into uracil by treatment with bisulfite whereas methylated $\mathrm{dCs}$ remain unchanged. Sequencing reveals the methylation sites by comparison with the unmodified DNA sequence. ${ }^{[20-22]}$ In methylation-specific PCRs, primers are employed, creating matched or mismatched primer-template termini. ${ }^{[23]}$ Amplicons are predominantly generated in the case of a matched primer-template pair. Thus, engineered DNA polymerases with higher discrimination ratios between matched and mismatched base pairs are leading to a more robust and accurate outcome of methylation-specific PCR. These enzymes are highly desired, and some examples are already commercially available. ${ }^{[24]}$

In this short review, we aim to highlight selected recent approaches covering the development of DNA polymerase variants for applications in biotechnology.

\section{Directed DNA Polymerase Evolution}

Native enzymes are the natural products of several million years of evolution and have adapted to support the survival of their host species. It is remarkable that several wild-type DNA polymerases are already well suited for complex biotechnological applications. However, directed evolution of enzymes ${ }^{[25,26]}$ has been employed successfully to obtain enzymes like DNA polymerases, with new or improved properties. In general, the directed evolution process of DNA polymerases can be divided into three steps. First, mutations are introduced throughout the whole gene or in selected regions resulting in a library of enzyme variants. ${ }^{[27,28]}$ After creation of an enzyme library, an expression and separation process is required. That step has to involve a connection between the specific enzyme genotype

[a] Dr. R. Kranaster, Prof. Dr. A. Marx

Fachbereich Chemie, Universität Konstanz

Universitätsstrasse 10, 78457 Konstanz (Germany)

Fax: $(+49) 7531-88-5140$

E-mail:andreas.marx@uni-konstanz.de

[b] Dr. R. Kranaster

New address: Department of Chemistry, University of Cambridge Lensfield Road, CB2 1EW Cambridge (UK) 
and its respective phenotype. Finally, the best enzyme has to be chosen by direct selection or screening approaches. All steps can be repeated iteratively until the desired feature is obtained (see Figure 1).

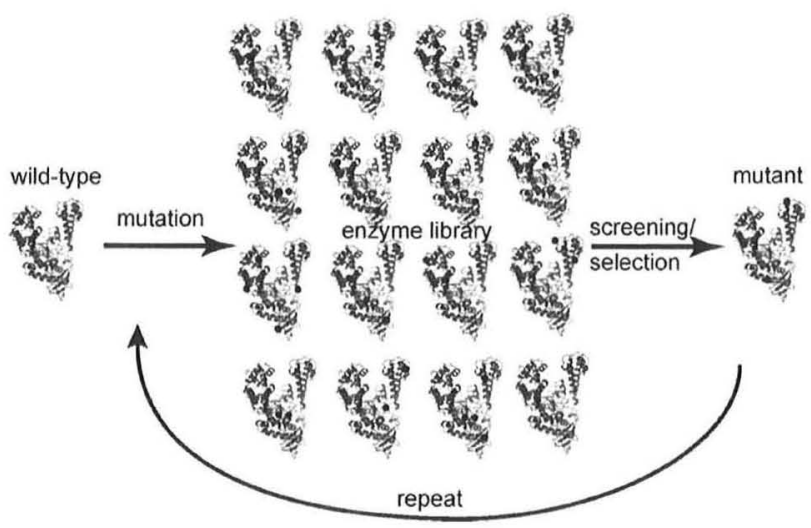

Figure 1. Strategy for the directed evolution of DNA polymerases. The wild type gene is randomly mutated (black dots symbolise mutations) and a library of mutants is generated. Mutants are evaluated by using suitable screening or selection methods to identify enzyme variants with new de sired features. The whole process can be repeated iteratively until satisfactory results are obtained.

Both selection and screening approaches have been reported to be suitable for the directed evolution of DNA polymerases. Reported selection methods employ phage display ${ }^{[29]}$ or a compartmentalised self-replication system. ${ }^{[30]}$

In phage display, DNA polymerase variants are expressed and displayed on the surface of a phage. The polymerase mutant displayed on the phage particle acts to convert a substrate linked to the phage particle into a desired product, which is then selected, for example by affinity chromatography. A successful outcome of this approach was a DNA polymerase, which was turned into an efficient RNA polymerase ${ }^{[31]}$ or in another case, in which DNA polymerases were developed with an expanded substrate spectrum. ${ }^{[29,32,33]}$ One disadvantage, however, could be that there is a high degree of crossreactions between a DNA polymerase on one phage and substrates attached to different ones. ${ }^{[29,31-33]}$

Holliger and co-workers employed a compartmentalised selfreplication (CSR) system ${ }^{[34]}$ to evolve DNA polymerases to extend mismatches and bypass common lesions that are found in ancient DNA. For instance they could identify engineered DNA polymerases that facilitate the recovery of genetic information from Pleistocene specimens. ${ }^{[30]}$ For a CSR method, each single DNA polymerase gene is separately encapsulated in a compartment formed by a heat-stable water-in-oil emulsion and is replicated by the respective DNA polymerase variant. This results in the enrichment of active variants that can be selected by employing the respective selection strategies.

In addition to selection methods, screening approaches of relatively small DNA polymerase libraries have also been successful in identifying interesting enzyme variants. In screening approaches, the different enzyme variants are separately ex- pressed (e.g., in multiwell microtiter plates) in a way that the phenotype is directly connected to the corresponding mutant. Subsequent screening reactions of mutants can be processed by nucleotide-incorporation assays, ${ }^{[35]}$ primer-extension reactions, ${ }^{[36]}$ or $\mathrm{PCR} .{ }^{[37]} \mathrm{PCR}$ screening results in a very high sensitivity due to the exponential enrichment of the product. Screening by primer extension is feasible by exploiting the fluorescence increase of minor-groove-binding dyes such as Sybr Green $\left.\right|^{[36]}$ or by incorporation of radioactive-labelled triphosphates. ${ }^{[35]}$ Successes in screening approaches have resulted in, for example, DNA polymerase variants resistant to inhibitors present in blood and soil samples, ${ }^{[18,38]}$ variants with increased reverse transcriptase activity, ${ }^{[39]}$ or with the capability to promote amplification from damaged templates. ${ }^{[40]}$

Loeb and co-workers ${ }^{[41]}$ employed a reporter plasmid assay for the selection of DNA polymerase I mutants with increased fidelity. They used a plasmid that contains a reporter gene (an antibiotic resistance gene) including an opal stop codon. Screening of mutants is possible by comparing the reversion frequencies of the wild-type variant with the mutant polymerases. Mutants with an increased fidelity lead to a lower reversion frequency than wild-type, which results in fewer $E$. coli colonies upon plating. In other approaches, the same research group developed a genetic complementation system in which active enzymes were selected from large DNA polymerase mutant libraries (e.g., human DNA polymerase $\beta$, Taq DNA polymerase) by complementing the action of $E$. coli DNA polymerase I in DNA polymerase I-deficient E. coli cells. ${ }^{[42]}$ Active enzymes were subsequently screened and entities with altered properties such as selectivity, DNA lesion bypass or RNA polymerase activity were identified. ${ }^{[43-45]}$

The above-mentioned methods for directed evolution of DNA polymerases are restricted to a single enzyme property for example, increased selectivity or ability of efficient processing of DNA lesions, respectively. Recently, a screening approach for the identification of multiple polymerase features in a parallel microarray system has been developed that might overcome this limitation. ${ }^{[46]}$ It offers the ability to screen in a multiplexed and parallel manner for several different enzyme features and new functions. The method is based on spatially separated, immobilised oligonucleotides that act as primers and address certain templates by specific hybridisation in a microarray format. It was shown that in this screening approach DNA polymerase libraries can be screened in nanoliter reaction volumes and interesting variants were identified. ${ }^{[46]}$

\section{Applications of Engineered DNA Polymerases}

\section{DNA polymerases for DNA amplification by PCR}

During PCR, a particular DNA sequence is enriched exponentially by amplification of a few copies or even a single copy of a unique template strand. PCR requires specific short DNA primers that are complementary to the target DNA region and define the amplicon's boundaries. Thermostable DNA polymerases like Taq DNA polymerase withstand several heating and cooling cycles, which are necessary to perform PCR. PCR is 
often monitored in real-time by measuring fluorescence intensities from dsDNA-sensitive dyes or FRET probes (e.g., TaqMan probe) during each PCR cycle. ${ }^{[1,47,48]}$ The amount of amplified DNA is therefore proportional to the fluorescence intensity. Real-time PCR methods and optional melting point analyses have shortened the handling time and further eliminate the necessity of time-consuming agarose gel analysis.

Undesired generation of unspecific amplicons occurs specifically in PCR with high GC contents, a high number of cycles and in multiplex PCRs. ${ }^{[3,49,50]}$ Mispriming to the wrong template or formation of primer dimers in which two primers bind to each other are considered to be the origin of false amplifcations. Mispriming occurs preferentially at lower temperatures. Thus, blocking the activity of the DNA polymerase at low temperatures has beneficial effects on the outcome of a PCR resulting in a lower probability of undesired amplicons. ${ }^{[35]}$ Currently, several "hot-start" methods are being used to circumvent the generation of unspecific reactions. $\mathrm{Mg}^{2+}$ ions, which are essential for catalytic activity, can be added manually after the first heating-up process. One approach uses sequestered magnesium ions in a heat unstable precipitate (ammonium magnesium phosphate), which then become accessible at high temperatures. ${ }^{[50]}$ Other strategies that avoid repeated opening of the sample tube thereby limiting the potential for contamination, employ paraffin wax separating the enzyme from the PCR primers. The wax melts at high temperatures and thereby liberates the enzyme. ${ }^{[51]}$ Chemically blocked PCR primers, containing one or two thermolabile 4-oxo-1-pentyl (OXP) phosphotriesters (PTE) at the $3^{\prime}$-terminal and 3'-penultimate ends prevent the primer extension from taking place at ambient temperatures (Scheme 1). ${ }^{[49]}$

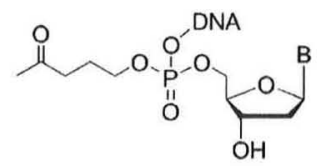

Scheme 1. Thermolabile 4-oxo-1-pentyl (OXP) phosphotriesters (PTE) at the 3 -terminal end of a primer strand. $\mathrm{B}=$ nucleobase.

Anti-polymerase antibodies inhibit the DNA polymerase up until the denaturation step at which they are then broken down due to elevated temperatures. ${ }^{[52]}$ Barnes and co-workers demonstrated that it was possible to evolve Taq DNA polymerase variants that are cold sensitive, resulting in suppressed enzymatic activity at low temperatures $\left(37^{\circ} \mathrm{C}\right)$, but they still exhibit normal activity above $68^{\circ} \mathrm{C} .^{[35]}$ They exploited a radioactive screening assay of polymerase mutants and interestingly, found mutations on the surface of the polymerase finger domain, remote to residues of the active site or involved in substrate binding indicating remote effects (Figure 2). The mutations are located the hinge point of a domain, which is proposed to undergo significant translocation during each nucleotide-incorporation step and thus possibly affecting the movement of the finger domains during nucleotide incorporation.

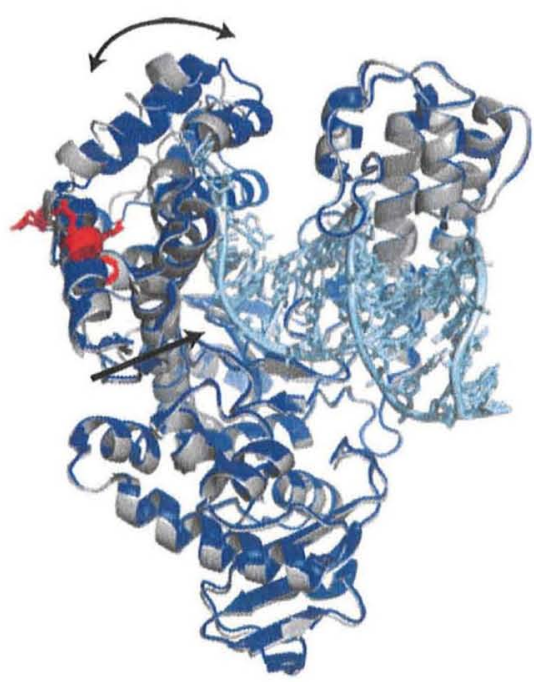

Figure 2. Overlay of open and closed-conformation (PDB ID: $2 \mathrm{KTQ}, 3 \mathrm{KTQ}^{[53]}$ ) of KlenTaq DNA polymerase with mutation sites (red) causing cold-sensitivity and influencing resistance against known inhibitors present in clinical and natural samples such as blood and soil. Ribbon model of open conformation (silver grey) and closed conformation (blue), DNA substrate (light blue). Movements in the fingers domain between both conformations are indicated with a black bent arrow. The mutation sites (red) are located in the hinge region. A straight black arrow indicates the area of the active site.

Processivity of DNA polymerases is defined as the average number of nucleotides added to one primer by one polymerase per association/dissociation step. Increased processivity enhances the DNA synthesis activity of a DNA polymerase, which results in shorter extension times in PCR as well as in a more robust and higher amplification yield. Williams and coworkers have shown that, by trapping a circular template to a solid-phase-bound $9^{\circ} \mathrm{N}$ DNA polymerase, the processivity of the enzyme can be increased from fewer than 20 nucleotides in the unmodified DNA polymerase up to several thousand nucleotides in the engineered complex due to prevention of diffusion of the template from the enzyme. ${ }^{[54]}$ Another successful approach for enhancing processivity of a DNA polymerase has been demonstrated by using protein fusion technology. Wang et al. fused Taq and Pyrococcus furiosus (Pfu) DNA polymerases with a heterologous, non-sequence specific, double-stranded DNA-binding domain Sso7d from Sulfolobus solfataricus, resulting in enzymes with increased processivities but without compromising catalytic activities or stabilities. ${ }^{[55]}$ By analysing every single primer extension product by PAGE, they showed in detail that wild-type Taq DNA polymerase added up to $35 \mathrm{nu}$ cleotides whereas the fusion Taq DNA polymerase variant produced products up to 200 nucleotides in length (Figure 3 ).

A similar approach exploiting the function of a fused affinity tag was developed by Loeb and co-workers through insertion of a thioredoxin-binding domain of T3 bacteriophage DNA polymerase in Taq DNA polymerase at an analogous position in the thumb domain. ${ }^{[5]}$ In presence of thioredoxin, which is assumed to act as a clamp, a 20-50-fold processivity enhancement was observed. 
A)
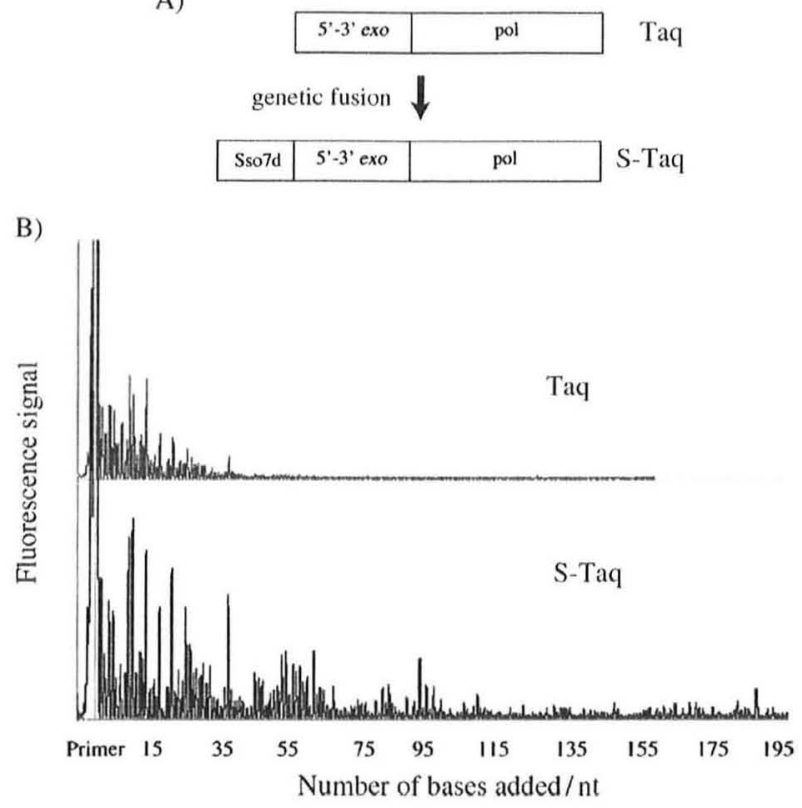

Figure 3. A) Genetic fusion strategy. Double-stranded DNA binding domain Sso7d from Sulfolobus solfataricus is N-terminal fused to DNA polymerase I from Thermus aquaticus (Taq) named S-Taq. B) Processivity analyses by sequencing gel by using a fluorescently labelled primer strand. Each fluorescent peak represents a single primer extension product. Fluorescence peaks of one trace are shown for the Taq polymerase in comparison with the fused S-Taq. Reprinted from ref. [55] with kind permission. Copyright: Oxford University Press, 2004.

\section{DNA polymerases in diagnostics}

Many common clinical and natural samples that require testing by PCR-based diagnostics, contain blood, plasma, hemoglobin, lactoferrin, serum IgG, soil extracts or humic acids, ${ }^{[18,38]}$ all of which are well known as DNA polymerase inhibitors and require time and costly sample preparation before PCR. DNA polymerases resistant to inhibitors from blood and soil samples would enable PCR without prior DNA purification, therefore enhancing the efficiency of relevant DNA tests. Barnes and coworkers have recently evolved Taq DNA polymerase mutants with enhanced resistance to various known inhibitors present in clinical and natural samples. ${ }^{[38]}$ An $\alpha$-helical region on the surface of the enzyme known as the "P-domain" (residues 704717) and specifically Glu708 turns out to confer increased resistance. Interestingly, some of the mutations in this domain have already been described to render the DNA polymerase cold sensitive (see Figure 2). ${ }^{[35]}$

DNA polymerases with an intrinsic high fidelity might increase the reliability of diagnostic systems. ${ }^{[57]}$ The M-helix is located at the junction of the fingers and palm subdomains and seems to be a determinant of fidelity. In particular, Loeb and co-workers have shown that mutations in this helix alter the base selection in E. coli DNA polymerase I without severely affecting the catalytic activity. ${ }^{[41]}$ Marx and co-workers increased the selectivity of a Taq DNA polymerase by nonpolar substitution mutations of three amino acids QVH (GIn, Val, His; resi- dues 782-784) of motif $C$, which is directly neighboured to catalytically essential amino acid residues. ${ }^{[36,37]}$ Screening of a $\sim 10,000$ member mutant library yielded several mutants with respective amino acid mutations like ILL (Ile, Leu, Leu) instead of QVH showing increased discrimination properties of cognate versus non-cognate primer/template pairs (see Figure 4). Moreover, the hypothesis concerning the involvement of motif $C$ in selectivity mechanisms has been corroborated by a successful design transfer of the finding for Taq DNA polymerase to Pfu DNA polymerase, a member of a different DNA polymerase sequence family. ${ }^{[58]}$ Furthermore, the obtained Pfu DNA polymerase mutants can be applied as useful tools in genotyping assays such as allele-specific real-time $\mathrm{PCR}^{[36]}$ and DNAchip-based allele-specific primer extensions. ${ }^{[59]}$ In both cases, employment of the engineered polymerase leads to a higher
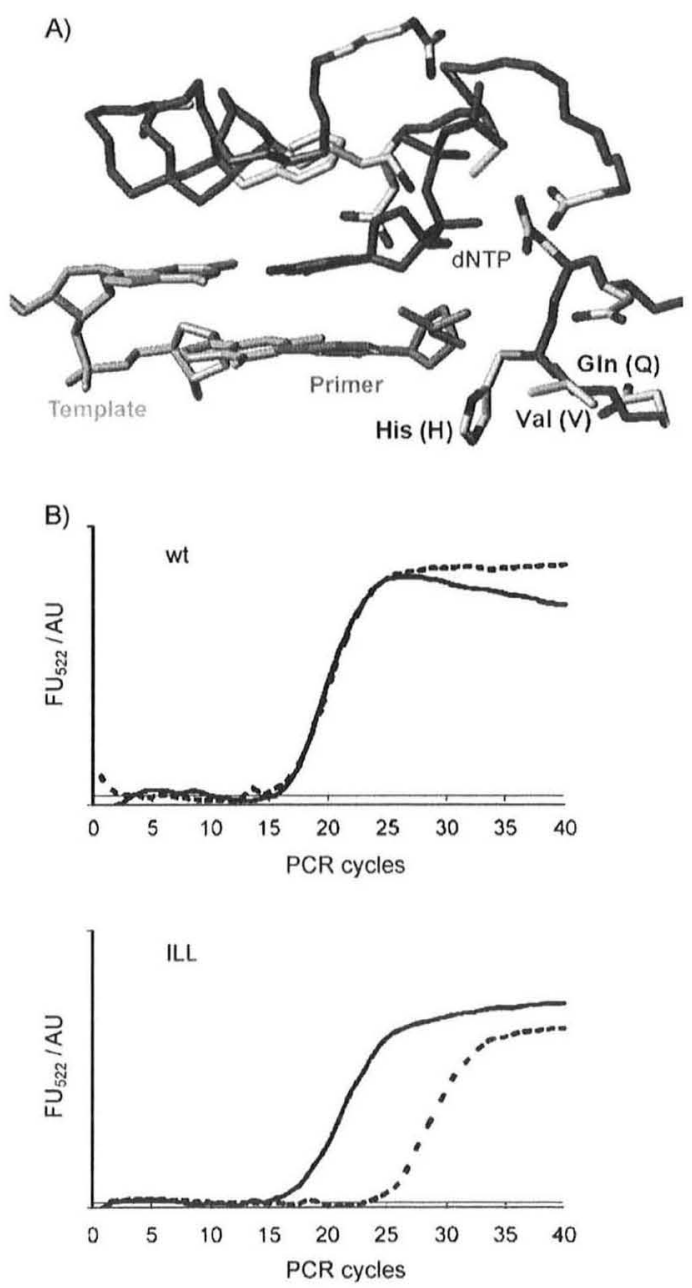

Figure 4. A) Depiction of active site residues of a Taq DNA polymerase showing some amino acids of motif $C(\mathrm{QVH})$ and the DNA primer-template duplex and incoming triphosphate (PDB ID: $3 K \mathrm{QQ}^{[53]}$ ). The $3^{\prime}$-primer terminus paired to the template, incoming dNTP and protein backbone are shown. B) Allele-specific real-time PCR curves with Taq DNA polymerase wild-type (wt) in comparison with a mutant (ILL (lle, Leu, Leu)). Solid lines: Amplification from complete matched primer template complex. Dotted lines: Amplification from primer template complex containing a single mismatch at the primer terminus. Reprinted from ref. [37]. Copyright: Wiley-VCH, 2007. 
allelic discrimination resulting in a more reliable detection system.

Pathogens like retroviruses and mRNA levels are usually detected by reverse transcription (RT) PCR. In the first step of RT $P C R$, the RNA target strand is reverse transcribed into the complementary DNA strand followed by amplification. Commercially available RT PCR kits usually consist of a blend of at least two different DNA polymerases: the reverse transcription is performed by a non-thermostable reverse transcriptase and the amplification step is performed by a thermostable DNA polymerase. The most critical step in this detection method is reverse transcription because RNA can form stable secondary structures, such as hairpins and G-quadruplexes, which complicate, or in the worst case even prevent the reverse transcription. ${ }^{[60,61]}$ Recently, Marx and co-workers have engineered a thermostable Taq DNA polymerase mutant that is able to reverse transcribe RNA templates and amplify the resulting DNA (see Figure 5). ${ }^{[39,60]}$ Thus, due to its thermostability, RT is feasible at high temperatures, which is on the one hand desired to weaken or melt secondary structure motifs. Thus, RT PCR from a G-quadruplex-bearing RNA template was feasible whereas amplification by using a commercially available RT PCR system failed (see Figure 5C).

In ancient DNA samples, for example, those derived from the extinct species like cave-bear or the Neanderthal man, damage like double-strand breaks and abasic sites are enriched. ${ }^{[62]}$ Amplification and sequencing requires that DNA polymerases efficiently overcome and amplify DNA from targets that contain these typical DNA lesions. Gloeckner et al. ${ }^{[40]}$ and $d^{\prime}$ Abbadie et al. ${ }^{[30]}$ described the successful directed evolution of DNA polymerases able to amplify DNA from highly damaged targets and exhibit increased lesion-bypass properties. Holliger and co-workers ${ }^{[30]}$ used a compartmentalised selection process whereas Marx and co-workers ${ }^{[40]}$ conducted a multi-well plate screening approach.

\section{Incorporation of modified nucleotides}

Engineered polymerases can be used for the production of artificial nucleic acid based oligomers. Holliger and co-workers have recently evolved a DNA polymerase that can efficiently incorporate and extend hydrophobic base analogues. ${ }^{[63]}$ They
A)

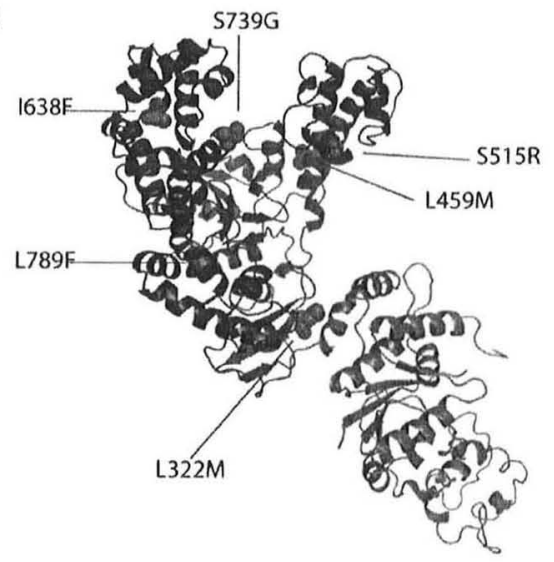

B)

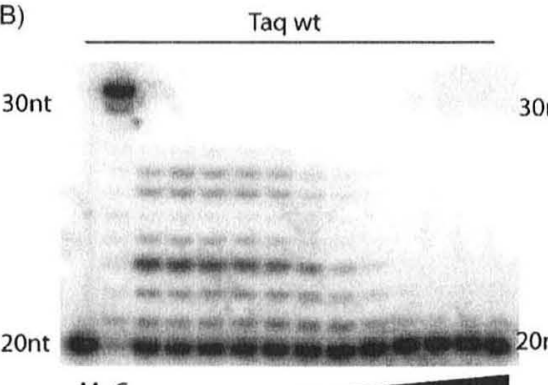

M C

$T\left(60-72^{\circ} \mathrm{C}\right)$

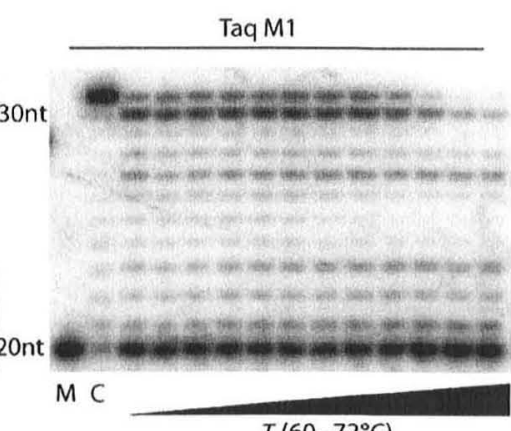

$T\left(60-72^{\circ} \mathrm{C}\right)$

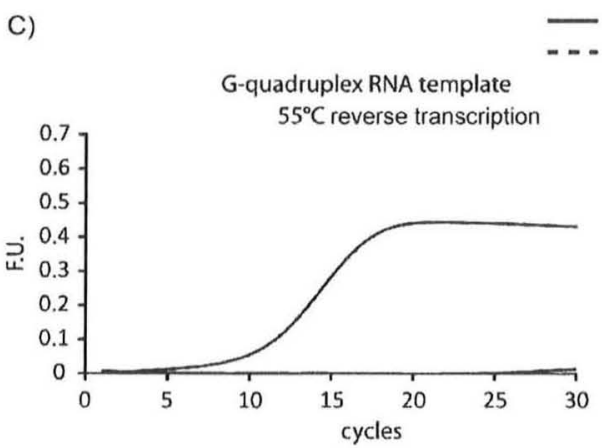

TaqM1

Titan One

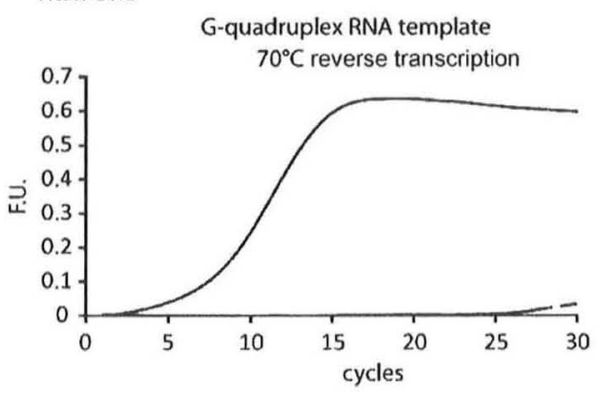

D) 5 '...-GGG UGG GUG GGU GGG UGG GUG GG-...3

Figure 5. A) The engineered Taq polymerase (Taq M1) comprises six mutations throughout the polymerase domain. B) Primer extension using a radioactively labeled primer bound to the RNA template demonstrates Taq M1's ability to reverse transcribe RNA. $M=$ marker; $C=$ control reaction by using a DNA template strand. C) Comparison of Taq M1 with a commercially available kit for one-step real-time RT PCR. Reverse transcription was performed at 55 and $70{ }^{\circ} \mathrm{C}$ before PCR amplification. The RNA template was bearing a G-quadruplex secondary structure. The respective RNA sequence is shown in D). Reprinted from ref. [60]. Copyright: Wiley-VCH, 2010. 
selected chimeric polymerase mutants from the genus Thermus for the incorporation of 5-nitroindole (d5NI) and its derivative 5-nitroindole-3-carboxamide (d5NIC). The selected DNA polymerase is a chimera between Thermus thermophilus and Thermus aquaticus and has 14 additional mutation sites throughout the whole DNA polymerase gene. In particular, it is able to form and extend several artificial base pairs like pyrene to abasic site, d5NI to abasic site and isocarbostyril to 7-azaindole. A generally observed pitfall is that polymerases that are more promiscuous and feature a broader substrate acceptance, can tend to exhibit reduced fidelity in incorporating the correct Watson-Crick pair. Holliger and co-workers report a moderate fivefold-increased nucleotide misincorporation rate compared to wild-type Taq DNA polymerase. ${ }^{[63]}$

\section{DNA polymerases in next-generation sequencing}

Most of the currently employed next-generation DNA-sequencing methods require DNA polymerases to insert the right nucleoside opposite the template strand and rely on the ability of DNA polymerases to efficiently process modified nucleotides. $^{[6,7]}$ For example, the sequencing technology devised by Illumina Inc. (previously Solexa) uses fluorescent reversible terminator deoxyribonucleotides (see Scheme $2 \mathrm{~A}$ and $\mathrm{B}$ ). ${ }^{[6]}$ These highly modified triphosphates bear a 3'-O-azidomethylene group, which terminates DNA synthesis after each single nucleotide incorporation step. All four dNTPs $(N=A, C, G$ and T) are additionally labelled with a different removable fluorophore to distinguish between them by stepwise fluorescence readout after each incorporation step. After readout, the $3^{\prime}-\mathrm{O}$ azidomethylene group and the fluorescent dye are chemically removed by reduction with tris(2-carboxyethyl)phosphine (TCEP). This liberates the $3^{\prime}-\mathrm{OH}$ and the next single incorporation cycle can commence. However, the selective incorporation as well as the extension of the growing strand with a remaining linker moiety (see Scheme 2B) by a DNA polymerase, had to be improved to ensure the efficient incorporation of these unnatural nucleotides. To achieve a sufficient sequencing setup, an engineered $9^{\circ} \mathrm{N}$ DNA polymerase variant was developed that harbours mutations at positions in the palm domain that are close to the deoxyribose moiety of the incoming dNTP, ${ }^{[64]}$

A very recent approach to increase acceptance of $3^{\prime}-\mathrm{OH}$ modifications useful for sequencing-by-synthesis techniques is described by Benner and co-workers. ${ }^{[65]}$ They have used "reconstructing evolutionary adaptive paths" (REAP) ${ }^{[6]}$ and analysed the history of DNA polymerase evolution particularly between viral and nonviral DNA polymerases, because viral polymerases are empirically known to have a higher acceptance for modified nucleotides than their nonviral counterparts. ${ }^{[67]}$ After construction and screening of a small combinatorial library of interesting sites (93 variants), they identified Taq DNA polymerase variants that accept the reversible terminators more efficiently than the wild-type. ${ }^{[65]}$

\section{Outlook}

In summary, recent achievements in the field of DNA polymerase engineering now provide a vast range of biotechnological applications. Less than 25 years have passed since the invention of $\mathrm{PCR},{ }^{[8]}$ and all the polymerases described in this review have evolved within the last eight years; this promises an exciting future for the field. It is obvious that custom-made DNA polymerases will lead to more robust and specific amplification systems. DNA sequencing with engineered enzymes will become a routine part of an individual's medical diagnosis. For example, DNA polymerases that discriminate between 5methyl $\mathrm{dC}$ and $\mathrm{dC}$ reliably could lead to diagnostic systems without time-consuming pretreatment of genetic samples with bisulfite or other chemicals, thus facilitating further progress in the field of epigenetics. The use of unnatural amino acids and artificial functional groups that are not represented in Nature's repertoire might even lead to a higher diversity of DNA polymerase structures and properties. ${ }^{[68]}$ First examples show that DNA polymerases can indeed tolerate artificial amino acids without the significant loss of activity. ${ }^{[69]}$ Future goals could be efficient enzymatic production and improved amplification of unnatural biopolymers ${ }^{[70,71]}$ such as L-DNA, peptide nucleic acids (PNA), ${ }^{[72]}$ locked nucleic acids (LNA), ${ }^{[73]}$ glycol nucleic acids (GNA), ${ }^{[74]}$ and threose nucleic acids (TNA). ${ }^{[75]}$ These artificial biopolymers could overcome current limitations such as instability, limited functional groups, bioavailability and immunogenicity. ${ }^{[71]}$ To conclude, engineered DNA polymerases already are and will be the workhorses in many biotechnological applications in the future, which is why this growing field of research is attractive to both industry and academia alike.

\section{Acknowledgements}

Scheme 2. A) 3'-O-azidomethylene and C5-modified triphosphate (thymidine as a representative) used in the sequencing technology from Illumina Inc. ${ }^{[6]}$ B) Remaining product after deprotection and cleavage of the fluorescent dye by treatment with TCEP.
The authors thank Beth Ashbridge and Dr. Eun-Ang Raiber for carefully reading the manuscript. We grate- 
fully acknowledge funding by the DFG and the BMBF (BioChancePLUS).

Keywords: directed evolution - DNA polymerase - pathogen detection · polymerase chain reaction - sequencing

[1] R. Beroukhim, C. H. Mermel, D. Porter, G. Wei, S. Raychaudhuri, J. Dono van, J. Barretina, J. S. Boehm, J. Dobson, M. Urashima, K. T. McHenry, R. M. Pinchback, A. H. Ligon, Y. J. Cho, L. Haery, H. Greulich, M. Reich, W. Winckler, M. S. Lawrence, B. A. Weir, K. E. Tanaka, D. Y. Chiang, A. J. Bass, A. Loo, C. Hoffman, J. Prensner, T. Liefeld, Q. Gao, D. Yecies, S. Signoretti, E. Maher, F. J. Kaye, H. Sasaki, J. E. Tepper, J. A. Fletcher, J. Tabernero, J. Baselga, M. S. Tsao, F. Demichelis, M. A. Rubin, P. A. Janne, M. J. Daly, C. Nucera, R. L. Levine, B. L. Ebert, S. Gabriel, A. K. Rustgi, C. R. Antonescu, M. Ladanyi, A. Letai, L. A. Garraway, M. Loda, D. G. Beer, L. D. True, A. Okamoto, S. L. Pomeroy, S. Singer, T. R. Golub, E. S. Lander, G. Getz, W. R. Sellers, M. Meyerson, Nature 2010, 463, 899.

[2] L. V. Wain, J. A. Armour, M. D. Tobin, Lancet 2009, 374, 340.

[3] J. N. Hirschhorn, M. J. Daly, Nat. Rev. Genet. 2005, 6, 95.

[4] E. R. Mardis, Adv. Genome Biol. 2006, 7, 112.

[5] S. T. Bennett, C. Barnes, A. Cox, L. Davies, C. Brown, Pharmacogenomics 2005, 6, 373

[6] D. R. Bentley, S. Balasubramanian, H. P. Swerdlow, G. P. Smith, J. Milton C. G. Brown, K. P. Hall, D. J. Evers, C. L. Barnes, H. R. Bignell, J. M. Boutell, J. Bryant, R. J. Carter, R. K. Cheetham, A. J. Cox, D. J. Ellis, M. R. Flatbush, N. A. Gormley, S. J. Humphray, L. J. Irving, M. S. Karbelashvili, S. M. Kirk H. Li, X. Liu, K. S. Maisinger, L. J. Murray, B. Obradovic, T. Ost, M. L. Parkinson, M. R. Pratt, I. M. Rasolonjatovo, M. T. Reed, R. Rigatti, C. Rodigh iero, M. T. Ross, A. Sabot, S. V. Sankar, A. Scally, G. P. Schroth, M. E. Smith, V. P. Smith, A. Spiridou, P. E. Torrance, S. S. Tzonev, E. H. Vermaas, K. Walter, X. Wu, L. Zhang, M. D. Alam, C. Anastasi, I. C. Aniebo, D. M. Bailey, I. R. Bancarz, S. Banerjee, S. G. Barbour, P. A. Baybayan, V. A Benoit, K. F. Benson, C. Bevis, P. J. Black, A. Boodhun, J. S. Brennan, J. A Bridgham, R. C. Brown, A. A. Brown, D. H. Buermann, A. A. Bundu, J. C. Burrows, N. P. Carter, N. Castillo, E. C. M. Chiara, S. Chang, R. N. Cooley, N. R. Crake, O. O. Dada, K. D. Diakoumakos, B. Dominguez-Fernandez, D. J. Earnshaw, U. C. Egbujor, D. W. Elmore, S. S. Etchin, M. R. Ewan, M. Fedurco, L. J. Fraser, K. V. Fuentes Fajardo, W. S. Furey, D. George, K. J. Gietzen, C. P. Goddard, G. S. Golda, P. A. Granieri, D. E. Green, D. L. Gus tafson, N. F. Hansen, K. Harnish, C. D. Haudenschild, N. I. Heyer, M. M. Hims, J. T. Ho, A. M. Horgan, Nature 2008, 456, 53.

[7] J. Eid, A. Fehr, J. Gray, K. Luong, J. Lyle, G. Otto, P. Peluso, D. Rank, P. Baybayan, B. Bettman, A. Bibillo, K. Bjornson, B. Chaudhuri, F. Christians, R. Cicero, S. Clark, R. Dalal, A. Dewinter, J. Dixon, M. Foquet, A. Gaertner, P. Hardenbol, C. Heiner, K. Hester, D. Holden, G. Kearns, X. Kong, R. Kuse, Y. Lacroix, S. Lin, P. Lundquist, C. Ma, P. Marks, M. Maxham, D. Murphy, I. Park, T. Pham, M. Phillips, J. Roy, R. Sebra, G. Shen, J. Sorenson, A. Tomaney, K. Travers, M. Trulson, J. Vieceli, J. Wegener, D. Wu, A. Yang, D. Zaccarin, P. Zhao, F. Zhong, J. Korlach, S. Turner, Science 2009 $323,133$.

[8] K. B. Mullis, F. A. Faloona, Methods Enzymol. 1987, 155, 335.

[9] D. G. Gibson, G. A. Benders, C. Andrews-Pfannkoch, E. A. Denisova, H. Baden-Tillson, J. Zaveri, T. B. Stockwell, A. Brownley, D. W. Thomas, M. A. Algire, C. Merryman, L. Young, V. N. Noskov, J. I. Glass, J. C. Venter, C. A. Hutchison III, H. O. Smith, Science 2008, 319, 1215.

[10] K. Porter-Jordan, E. I. Rosenberg, J. F. Keiser, J. D. Gross, A. M. Ross, S. Nasim, C. T. Garrett, J. Med. Virol. 1990, 30, 85.

[11] A. M. Wang, M. V. Doyle, D. F. Mark, Proc. Natl. Acad. Sci. USA 1989, 86 9717.

[12] a) M. Weidmann, K. Armbruster, F. T. Hufert, J. Clin. Virol. 2008, 42, 326 b) S. O. De Paula, B. A. Fonseca, Braz. J. Infect. Dis. 2004, 8, 390.

[13] M. Strerath, A. Marx, Angew. Chem. 2005, 117, 8052; Angew. Chem. Int. Ed. 2005, 44, 7842

[14] M. Strerath, I. Detmer, J. Gaster, A. Marx, Methods Mol. Biol. 2007, 402, 317

[15] A. C. McHardy, B. Adams, PLoS Pathog. 2009, 5, e1000566.

[16] S. Merler, M. Ajelli, Proc. Biol. Sci. 2010, 277, 557.

[17] S. O. De Paula, B. A. Fonseca, Braz. J. Infect. Dis. 2004, 8, 390.

[18] Z. Zhang, M. B. Kermekchiev, W. M. Barnes, J. Mol. Diagn. 2010, 12, 152.
[19] R. Lister, M. Pelizzola, R. H. Dowen, R. D. Hawkins, G. Hon, J. Tonti-Filippini, J. R. Nery, L. Lee, Z. Ye, Q. M. Ngo, L. Edsall, J. Antosiewicz-Bourget, R. Stewart, V. Ruotti, A. H. Millar, J. A. Thomson, B. Ren, J. R. Ecker, Nature 2009, 462, 315.

[20] C. A. Bormann Chung, V. L. Boyd, K. J. McKernan, Y. Fu, C. Monighetti, H. E. Peckham, M. Barker, PLoS One 2010, e9320.

[21] H. Hayatsu, Proc. Jpn. Acad. Ser. B Phys. Biol. Sci. 2008, 84, 321.

[22] M. Frommer, L. E. McDonald, D. S. Millar, C. M. Collis, F. Watt, G. W. Grigg, P. L. Molloy, C. L. Paul, Proc. Natl. Acad. Sci. USA 1992, 89, 1827.

[23] S. Derks, M. H. Lentjes, D. M. Hellebrekers, A. P. de Bruine, J. G. Herman, M. van Engeland, Cell. Oncol. 2004, 26, 291.

[24] QIAGEN GmbH, QIAGEN Strasse 1, 40724 Hilden, http://www1.qiagen. com/, EpiTect MSP Kit.

[25] N. J. Turner, Nat. Chem. Biol. 2009, 5, 567.

[26] C. A. Tracewell, F. H. Arnold, Curr. Opin. Chem. Biol. 2009, 13, 3.

[27] S. Brakmann, Cell. Mol. Life Sci. 2005, 62, 2634.

[28] R. C. Holmberg, A. A. Henry, F. E. Romesberg, Biomol. Eng. 2005, 22, 39.

[29] S. Vichier-Guerre, S. Ferris, N. Auberger, K. Mahiddine, J. L. Jestin, Angew. Chem. 2006, 118, 6279; Angew. Chem. Int. Ed. 2006, 45, 6133.

[30] M. d'Abbadie, M. Hofreiter, A. Vaisman, D. Loakes, D. Gasparutto, J Cadet, R. Woodgate, S. Paabo, P. Holliger, Nat. Biotechnol. 2007, 25, 939.

[31] G. Xia, L. Chen, T. Sera, M. Fa, P. G. Schultz, F. E. Romesberg, Proc. Natl. Acad. Sci. USA 2002, 99, 6597.

[32] a) M. Fa, A. Radeghieri, A. A. Henry, F. E. Romesberg, J. Am. Chem. Soc. 2004, 126, 1748; b) S. Vichier-Guerre, S. Ferris, N. Auberger, K. Mahiddine, J.-L. Jestin, Angew. Chem. 2006, 118, 6279-6283; Angew. Chem. Int. Ed. 2006, 45, 6133-6137.

[33] A. M. Leconte, L. Chen, F. E. Romesberg, J. Am. Chem. Soc. 2005, 127, 12470.

[34] a) F. J. Ghadessy, P. Holliger, Methods Mol. Biol. 2007, 352, 237; b) F. J. Ghadessy, J. L. Ong, P. Holliger, Proc. Natl. Acad. Sci. USA 2001, 98, 4552; c) F. J. Ghadessy, N. Ramsay, F. Boudsocq, D. Loakes, A. Brown, S. Iwai, A. Vaisman, R. Woodgate, P. Holliger, Nat. Biotechnol. 2004, 22, 755; d) J. L. Ong, D. Loakes, S. Jaroslawski, K. Too, P. Holliger, J. Mol. Biol. 2006, 361, 537.

[35] M. B. Kermekchiev, A. Tzekov, W. M. Barnes, Nucleic Acids Res. 2003, 31 , 6139.

[36] D. Summerer, N. Z. Rudinger, I. Detmer, A. Marx, Angew. Chem. 2005 , 117, 4791; Angew. Chem. Int. Ed. 2005, 44, 4712.

[37] M. Strerath, C. Gloeckner, D. Liu, A. Schnur, A. Marx, ChemBioChem 2007, 8, 395

[38] M. B. Kermekchiev, L. I. Kirilova, E. E. Vail, W. M. Barnes, Nucleic Acids Res. 2009, 37, e40.

[39] K. B. Sauter, A. Marx, Angew. Chem. 2006, 118, 7795; Angew. Chem. Int. Ed. 2006, 45, 7633 .

[40] C. Gloeckner, K. B. Sauter, A. Marx, Angew. Chem. 2007, 119, 3175; Angew. Chem. Int. Ed. 2007, 46, 3115.

[41] E. Loh, J. Choe, L. A. Loeb, J. Biol. Chem. 2007, 282, 12201.

[42] M. Camps, L. A. Loeb, Methods Mol. Biol. 2003, 230, 11

[43] A. Skandalis, L. A. Loeb, Nucleic Acids Res. 2001, 29, 2418.

[44] P. H. Patel, H. Kawate, E. Adman, M. Ashbach, L. A. Loeb, J. Biol. Chem. 2001, 276, 5044.

[45] A. Shinkai, P. H. Patel, L. A. Loeb, J. Biol. Chem. 2001, 276, 18836.

[46] R. Kranaster, A. Marx, Angew. Chem. 2009, 121, 4696; Angew. Chem. Int. Ed. 2009, 48, 4625 .

[47] P. M. Holland, R. D. Abramson, R. Watson, D. H. Gelfand, Proc. Natl. Acad. Sci. USA 1991, 88, 7276.

[48] J. Wilhelm, A. Pingoud, ChemBioChem 2003, 4, 1120.

[49] A. V. Lebedev, N. Paul, J. Yee, V. A. Timoshchuk, J. Shum, K. Miyagi, J. Kellum, R. I. Hogrefe, G. Zon, Nucleic Acids Res. 2008, 36, e131.

[50] W. M. Barnes, K. R. Rowlyk, Mol. Cell. Probes 2002, 16, 167.

[51] D. R. Sparkman, PCR Methods Appl. 1992, 2, 180.

[52] D. E. Kellogg, I. Rybalkin, S. Chen, N. Mukhamedova, T. Vlasik, P. D. Siebert, A. Chenchik, Biotechniques 1994, 16, 1134

[53] Y. Li, S. Korolev, G. Waksman, EMBO J. 1998, 17, 7514.

[54] J. G. Williams, D. L. Steffens, J. P. Anderson, T. M. Urlacher, D. T. Lamb, D. L. Grone, J. C. Egelhoff, Nucleic Acids Res. 2008, 36, e121.

[55] Y. Wang, D. E. Prosen, L. Mei, J. C. Sullivan, M. Finney, P. B. Vander Horn, Nucleic Acids Res. 2004, 32, 1197

[56] J. F. Davidson, R. Fox, D. D. Harris, S. Lyons-Abbott, L. A. Loeb, Nucleic Acids Res. 2003, 31, 4702. 
[57] B. Gilje, R. Heikkila, S. Oltedal, K. Tjensvoll, O. Nordgard, J. Mol. Diagn. 2008, 10, 325.

[58] N. Z. Rudinger, R. Kranaster, A. Marx, Chem. Biol. 2007, 14, 185.

[59] R. Kranaster, P. Ketzer, A. Marx, ChemBioChem 2008, 9, 694.

[60] R. Kranaster, M. Drum, N. Engel, M. Weidmann, F. T. Hufert, A. Marx, Biotechnol. J. 2010, 5, 224.

[61] T. W. Myers, D. H. Gelfand, Biochemistry 1991, 30, 7661

[62] A. J. Hansen, D. L. Mitchell, C. Wiuf, L. Paniker, T. B. Brand, J. Binladen, D. A. Gilichinsky, R. Ronn, E. Willerslev, Genetics 2006, 173, 1175.

[63] D. Loakes, J. Gallego, V. B. Pinheiro, E. T. Kool, P. Holliger, J. Am. Chem. Soc. 2009, 131, 14827.

[64] "Modified Polymerases for improved Incorporation of Nucleotide Analogues", G.P. Smith, et al. PCT International publication number WO2005/024010, 2005.

[65] F. Chen, E. A. Gaucher, N. A. Leal, D. Hutter, S. A. Havemann, S. Govindarajan, E. A. Ortlund, S. A. Benner, Proc. Natl. Acad. Sci. USA 2010, 107, 1948.

[66] E. A. Gaucher in Ancestral Sequence Reconstruction, (Ed.: David A. Liberles), Oxford University Press, New York, 2007, pp. 20-33.
[67] J. Horlacher, M. Hottiger, V. N. Podust, U. Hubscher, S. A. Benner, Proc. Natl. Acad. Sci. USA 1995, 92, 6329.

[68] N. Budisa, Engineering the Genetic Code; Wiley-VCH, Weinheim, 2006.

[69] B. Holzberger, M. Rubini, H. M. Möller, A. Marx, Angew. Chem. 2010, 122 , 1346; Angew. Chem. Int. Ed. 2010, 49, 1324.

[70] D. Loakes, P. Holliger, Chem. Commun. 2009, 4619.

[71] Y. Brudno, D. R. Liu, Chem. Biol. 2009, 16, 265.

[72] P. E. Nielsen, Methods Mol. Biol. 2002, 208, 3.

[73] R. N. Veedu, J. Wengel, Mol. Biosyst. 2009, 5, 787.

[74] J. J. Chen, C. H. Tsai, X. Cai, A. T. Horhota, L. W. McLaughlin, J. W. Szostak, PLoS One 2009, 4, e4949.

[75] J. K. Ichida, A. Horhota, K. Zou, L. W. McLaughlin, J. W. Szostak, Nucleic Acids Res. 2005, 33, 5219. 